\title{
Zinc Finger SWIM Domain-Containing Protein 4
}

National Cancer Institute

\section{Source}

National Cancer Institute. Zinc Finger SWIM Domain-Containing Protein 4. NCI

Thesaurus. Code C150357.

Zinc finger SWIM domain-containing protein 4 (989 aa, 110 kDa) is encoded by the human ZSWIM4 gene. This protein may be involved in zinc-dependent protein-protein or protein-DNA interactions. 